\title{
Cüneyd-i Bağdâdî̀nin Halifesi Ebû Muhammed el-Cerîrî: Hayatı ve Tasavvufî Görüşleri
}

Abu Muhammad al-Jarīi as the Successor of Junayd al-Baghdadī: His Life and Șüfì Views

Arş. Gör. Dr.

\section{Yakup PEKDOĞRU}

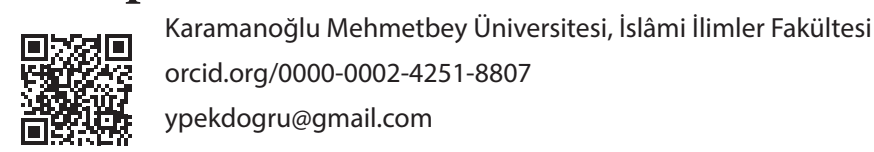

Arş. Gör.

\section{Harun ALKAN}

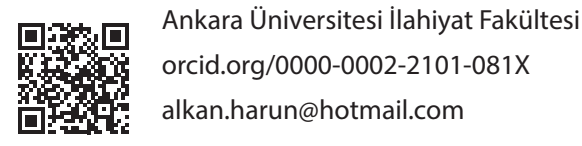




\section{Sufinge}

240

\section{Öz}

Bu makalenin amacı Cüneyd-i Bağdâdî’nin halifesi olan Ebû Muhammed el-Cerîrînnin hayatını ve tasavvufi görüşlerini ortaya koymaktır. Cüneyd-i Bağdâdî Bağdat’ta yaşamış bir sufidir. O, hem yaşadığı dönemde hem de kendinden sonra övgüyle bahsedilen sufiler arasındadır. Tasavvuf başta olmak üzere diğer dini alanlarda ilmi yetkinliği her kesim tarafından dile getirilmektedir. Onun bu özelliği dayısının kendisine tavsiyesiyle ortaya çıtı̆̆ğı söylenebilir. Cüneyd-i Bağdâdî sufîler arasında "seyyidü’t-taife" lakabıyla anılmaktadır. Ebû Muhammed el-Cerîrî ise kaynaklarda onun halifesi diye belirtilmektedir. Cüneyd-i Bağdâdînnin birçok halifesi vardır ancak rivayetlerde "Cerîrî onun yerine geçti, Cüneyd onu işaret etti" gibi hususlar zikredilmektedir. Dolayısıyla Cerîrînnin halifeliği diğerlerine nazaran ön plandadır. Ebû Muhammed el-Cerîrî diğer sûfîler gibi bazı konulara dair açıklamalarda bulunmaktadır. Bunlar arasında tasavvufi düşüncedeki nefs, marifet, tevhid, iman, ihlas gibi konular vardır. Ancak zikredilen konulara getirdiği yorumlar bağlamları bulunmadığı için yer yer birer cümleyle dile getirilmişlerdir. $\mathrm{Bu}$ makalede önce Cerîrînnin hayatına ve onun Cüneyd-i Bağdâdî ile ilişkisine sonra Cerîrî̀nin tasavvufi görüşlerine değinilmiştir.

Anahtar Kelimeler: Ebu Muhammed el-Cerîrî, Cüneyd-i Bağdâdî, Nefs, Marifet, Tevhid.

\section{Abstract}

This article aims to reveal the life and șūfĩ views of Abu Muhammad al- Jarīīi, the successor of Junayd al-Baghdādī. Junayd al-Baghdādī, a șūfî lived in Baghdad, is among the șūfīs that are praised by the people in both his contemporary period and later. His scientific competence in other religious fields, especially in Șūfissm, is recognized by all groups. It can be said that this feature of him emerged with the advice of his uncle. Junayd is known with the nickname "lord of the șūfìs" among Ṣufîs. Abu Muḥammad al- Jarīrī has been described as "the successor of Junayd" in the sources. There are many successors of Junayd al-Baghdādī, however, the narratives indicate that "Jarīīi has replaced Junayd and Junayd designated Jarīī after himself". Therefore, the successor of Jarīīi is in the foreground compared to the others. Abu Muhammad al- Jarīī made statements on some matters, including soul (nafs), mystical knowledge (ma'rifah), monotheism (tawhīd), belief, and sincerity in șūfĩ thought, like other șūfîs. However, sometimes, his comments on these mentioned topics are expressed with one sentence only because of the lack of context. This article initially examines the life of Jarïrī and his relationship with Junayd and later talks about șūfĩ views of Jarīīi.

Keywords: Abu Muhammad al- Jarīīī, Junayd al-Baghdadī, Nafs, Ma’rifah, Tawhīd. 


\section{Giriş}

Q ăgdat, İslâm tarihi ve ilimleri açısından önemli bir şehirdir. Kuruluşundan sonra önemli bir merkez haline gelen şehir, zamanla dini ilimlerin de kesişme noktası olmuştur. Dolayısıyla dini ilimleri temsil eden ulema ve bu alanlarda eğitim almak isteyen öğrenciler farklı bölgelerden Bağdat’a gelmişlerdir. Zikredilen dini ilimler içerisinde tasavvuf özellikle 3./9. asırda daha belirgindir. Bağdat'ta müşahede edilen dini ilimlerdeki canlılığı tasavvuf sahasında da görmek mümkündür.

Tasavvuf tarihine yönelik çalışmalarda Bağdat'ta neşvünema bulan tasavvufun şehrin adıyla ekol oluşturduğu ifade edilmektedir. ${ }^{1}$ Bu ekolün şüphesiz temsilcileri de bulunmaktadır. Bunlar arasında Ma'ruf Kerhî, Haris el-Muhâsibî, Cüneyd-i Bağdâdî, Ebû Muhammed el-Cerîrî gibi birçok isim bulunmaktadır. Mezkûr isimler arasında "seyyidü’t-tâife" diye bilinen Cüneyd-i Bağdâdî, Bağdat sûfîlerinin en önemlisidir.

Cüneyd-i Bağdâdî hem tasavvufta hem de diğer dini disiplinlerde yetkinliği kabul edilen bir sûfîdir. Onun yetiştirdiği birçok öğrenci vardır. Bunlardan biri de Ebû Muhammed el-Cerîrî̀dir. Makalemizde Ebû Muhammed el-Cerîrînin hayatı, Cüneyd-i Bağdâdî ile ilişkisi ve tasavvufi görüşleri ele alınacaktır.

\section{Hayatı}

Ebû Muhammed el-Cerîrînin doğum tarihi hakkında bilgi bulunmamaktadır. Cerîrînnin isminin Ahmed b. Muhammed b. el-Hüseyin, Hasan b. Muhammed ve Abdullah b. Yahya olduğuna dair rivâyetler vardır. Tarihçi Bağdâdî̀ye göre isminin Ahmed b. Muhammed b. el-Hüseyin olduğu diğerlerine nazaran daha doğrudur; ancak künyesi ismine göre daha çok kullanılmaktadır. ${ }^{2}$ Ebû Abdirrahmân Muhammed b. el-Hüseyn b. Muhammed es-Sülemî (ö. 412/1021) Cerîrînnin isimleri arasında zikredilen Abdullah b. Yahya'nın doğru olmadığını söyler. ${ }^{3}$ Kuşeyrî ise onun

1. bkz. Hasan Kamil Yılmaz, Anahatlarıyla Tasavvuf ve Tarikatlar (İstanbul: Ensar Neşriyat, 2007), 118-122.

2. Hatîb el-Bağdâdî, Târîhu Bă̆dâd (Beyrut: Dâru'l-Garbi'l-İslâmi, 2002), 6/116.

3. Ebû Abdurrahmân es-Sülemî, Tabakâtu's-sûfiyye, çev. Abdurrezzak Tek (Bursa: Bursa Akademi, 2018), 154. 
ismini "Ebû Muhammed Ahmed b. Muhammed b. el-Hüsyin el-Cerîr̂̂" diye kaydetmektedir. ${ }^{4}$

Ebû Muhammed el-Cerîrî, hayatını Bağdat'ta geçirmiştir. Rivâyetlere göre yüz yıl yaşamıştır. Vefat tarihine dair farklılıklar bulunsa da hicri üçüncü asırda yani iki yüzlü yılların başında doğduğu ve hac ve umre ibadeti dışında ölümüne kadar Bağdat'ta bulunduğu söylenebilir. ${ }^{5}$ Bağdat hem İslâm dünyasının hem de tasavvuf tarihinin önemli merkezlerinden biridir. Abbasi yöneticilerinin girişimleriyle Bağdat’ta entelektüel faaliyetlerde hissedilir derecede artış gerçekleşmiş ve sonraki asırları da etkileyen "tercüme hareketleri” nin merkezi bu şehir olmuştur. Bu ortamda sûfîler de kendilerini göstermiştir. ${ }^{6}$

Bahsi geçen sûfîler Bağdat'ta tasavvufun gelişimine katkıda bulundukları gibi aynı zamanda tasavvuf tarihinin de önemli simalarını oluşturmuşlardır. Tasavvuf tarihi kitaplarında zikredilen "sahv" ve "sekr" ekolün temsilcileri Cüneyd-i Bağdâdî (ö. 297/909) ve Hallac-1 Mansur (ö.309/922) Bağdat’ta karşımıza çıkmaktadırlar. ${ }^{7}$ Cüneyd-i Bağdâdî ve onun öğrencileri/müritleri şehrin tasavvufî kültüründe önemli bir yere sahiptirler. Bunlardan biri de Cüneyd-i Bağdâdî’nin halifesi Ebû Muhammed el-Cerîrî̀dir. Diğger yandan "Maruf Kerhi (ö.200/815-816 [?]), Serî es-Sakatî (ö. 251/865), Haris el-Muhasibî (ö. 243/857), Ebû Said el-Harrâz (ö.277/890 [?]), Ebu'l-Hüseyin en-Nûri (ö. 295/908), Rüveym b. Ahmed (ö. 303/915-916)" gibi isimler de Bağdat'ın önemli sûfîleri arasında yer almaktadır. ${ }^{8}$

Ebû Muhammmed el-Cerîrî̀nin hayatının safhaları hakkında ayrıntılı bilgi kaynaklarda bulunmamaktadır. İlmi müktesebatıyla ilgili rivâyetler,

4. Abdülkerîm b. Hevâzin el-Kuşeyrî, er-Risâletü'l-Kuşeyriyye (Beyrut: Dâru'l-Minhâc, 2017), 180; Ayrıca bkz. Ebû Abdillâh Şemsüddîn ez-Zehebî, Siyeru a'lâmi'n-nübelâ (Kahire: Dâru'lHadîs, 2006), 11/286.

5. Vefatıyla ilgili bilgi ileride verilecektir. Kelâbâzî̉nin aktardığı bir rivâyette Cerîrî vefatı anında yüz yaşını biraz aşmış olduğu zikredilmektedir. bkz. Muhammed b. İbrâhim el-Kelâbâzî, et-Taarrufli-mezhebi ehli't-tasavvuf (Beyrut: Dâru'l-Kütübi'l-İlmiyye, 2011), 166-167.

6. Mehmet Necmeddin Bardakçı, İslâm Tasavvuf Dǚs̈üncesinin Teşekkülü (İstanbul: Rağbet Yayınları, 2020), 192-193; Abdülkerim Özaydın, "Bağdat” Türkiye Diyanet Vakfi İslâm Ansiklopedisi (İstanbul: TDV Yayınları, 1991), 4/437.

7. Ekoller hakkında ayrıntılı bilgi için bkz. Bardakçı, İslâm Tasavvuf Düşüncesinin Teşekkülü, 194-272.

8. Bardakçı, İslâm Tasavvuf Düşüncesinin Teşekkülü, 194. 
onun tasavvuf ${ }^{9}$ haricinde fikıh ve fikıh usulü alanında da yetkinliğe sahip olduğunu iddia etmektedir. ${ }^{10}$ Cerîrî, Bağdat'ta "sûfîlerin büyükleri" arasında zikredilmektedir. ${ }^{11}$

Tarihi kaynaklarda Cerîrî̀nin 292/904 yllında Mekke'ye gittiği rivâyet edilir. Bu gidişin hac ya da umre niyetiyle yapılıp yapılmadığı net değildir. Mekke'de itikafa girdiği zikredilen Cerîrînnin “ne yemek yedi ne uyudu ne duvara yaslandı ne de ayaklarmı uzattı" ifadeleriyle itikaftaki durumu anlatılır. ${ }^{12}$ Cerîrînnin bu davranışı aynı dönemde Mekke'de bulunan Ebu Bekir Kettânî’nin (ö. 322/933) dikkatini celbetmiştir. Zira böyle bir tutum, herkesin güç yetirebileceği sınırları aşmaktadır. Kettânî’nin de bir sûfî olduğu göz önüne alınırsa zikredilen durumun büyüklüğü daha açık hale gelir. Kettânî, onun bu şaşılası halinden dolayı Cerîrîye "bu şekilde bir itikafa nasıl güç yetiriyorsun" diye sorar. O ise: "Hakk, bâtınımı biliyor ve zâhirime yardım ediyor" diye cevap verir. ${ }^{13}$ Cerîrî, Kettânî̀ye verdiği cevapla hem teslimiyete hem de Hakk'ın iradesine vurgu yapmaktadır. Onun, Kettânî’nin yanı sıra Bağdat'taki diğer sûfîlerle de ilişkisi bulunmaktadır.

Cerîr̂̂’nin ölüm tarihi hakkında farklılıklar bulunmaktadır. Kaynakların bildirdiğine göre bu tarihler 304/916, 311/923 ${ }^{14}$ ve 312/924'tür. Cerîrî tekrar hac ibadetini yerine getirmek için 311/923 y1lında Mekke'ye gitmiş ve 312/924'te Muharrem ayında Mekke'den dönerken “Hubeyr Vakası”nda şehit edilmiştir. ${ }^{15}$ Ebû Abdurrahman es-Sülemî, Bağdat'ta vefat ettiğini belirtir ama Bağdat yolunda vefat ettiğini söylemek daha doğru gözükmektedir. ${ }^{16}$ Vakanın bölgedeki önemi ve etkisi dolayısıyla

\footnotetext{
9. Kuşeyrî Cerîrî̀nin tasavvuf ilmindeki yetkinliğini haber vermektedir. bkz. Kuşeyrî, er-Risâletü'l-Kuşeyriyye, 180.

10. Ebu'l-Hasan Ali b. Osman el-Hücvirî, Keşfu'l-mahcûb, çev. Süleyman Uludağ (İstanbul: Dergâh Yayınları, 2010), 211; Ferîdüddîn Attâr, Tezkiretü’l-evliyâ, çev. Süleyman Uludağ (İstanbul: Kabalcı Yayınevi, 2007), 523; Mustafa Kara, "Ebû Muhammed el-Cerîrî”, Türkiye Diyanet Vakfi İslâm Ansiklopedisi (İstanbul: TDV Yayınları, 1994), 10/190 Cerîrînnin fıkıh ve fıkıh usûlü ilmiyle iştigaline dair zikredilen kaynaklardan başka bir yerde herhangi bir bilgiye ve herhangi bir konuya dair içtihadına rastlayamadık.

11. Bağdâdî, Târîhu Bă̆dâd, 6/116.

12. Sûfîler bu tarz davranışların varlığg hakkında bilgi vermektedirler. Edep konusunda değerlendirilebilecek bu tutumlar Hakk'la kurulan ilişkideki inceliği yansıtması bakımından önemlidir. bkz. Kuşeyrî, er-Risâletü'l-Kuşeyriyye, 595.

13. Bağdâdî, Târîhu Bă̆dâd, 6/116; Attâr, Tezkiretü'l-evliyâ, 523.

14. Sülemî, Tabakât, 154; Bağdâdî, Târîhu Bă̆dâd, 6/116; Kuşeyrî, er-Risâletü'l-Kuşeyriyye, 180; Attâr, Tezkiretü'l-evliyâ, 523.

15. Zehebî, Siyeru a'lâmi’n-nübelâ, 11/286.

16. Sülemî, Tabakât, 154.
} 
o yıla "Hubeyr Yıllı" da denilmektedir. ${ }^{18}$ Cerîrî̀nin "Hubeyr Vakası"nda vefat ettiğine dair kaynaklar ittifak halindedir. "Hubeyr Vakası" 312/924 yllında meydana geldiğine göre 304/916'da vefat ettiği makul değildir. Cerîrînnin bu ikinci ve son haccı olmalıdır, zira kaynaklar onun başka bir haccindan bahsetmemektedir.

Cerîrî̀nin vefatına ilişkin iki rivâyet vardır. Birincisi, onun "Hubeyr Vakası"nda bir deve tarafından ezildiğidir. ${ }^{19}$ İkincisi ise bu vakada susuz kalarak öldügüdür. $\mathrm{Bu}$, hem tarih kaynaklarında yer almakta hem de Kelâbâzînnin ismini vermediği bir dervişin konuya dair anlatısında bulunmaktadır. ${ }^{20}$ Anlatıya göre derviş, bu hadisede kendisini kurtarmıştır. Belli bir süre sonra tekrar vakıanın geçtiği yere gelen derviş Cerîrî̀i görür ve aralarında şu konuşma geçer:

"Ey şeyh! Neden dua etmiyorsun şu durumdan kurtulmak için? O: "Ettim fakat (Allah) 'Ben istediğimi yaparım," dedi. Derviş soruyu tekrarladı. Cerîrî: "Bu vakit, dua vakti değildir. Razı ve teslim olma vaktidir." "Bir ihtiyacın var mı?", diye sordum. "Çok susadım," dedi. Ona su getirdim. Suyu içmeye yeltendi ama bana bakarak: "Şunlar susuz ve su içiyorum, bu açgözlülüktür, dedi ve suyu bana verdi, hemen sonra vefat etti.".21 Vefatından sonra onun hakkında zikredilen hikâye ise oldukça ilginçtir. Hikâye, Ahmed b. Rûzbâri’ye (ö. 322/934) aittir. O şöyle söyler: "Vakadan bir yıl sonra Cerîrî̀yi dizleri göğsüne yaslanmış ve Allah'ı işaret eder şekilde buldum."22

17. "Hubeyr Vakası" Karmâtîlerin hacdan dönen Müslümanlardan bazılarını şehit ettiği bazılarını da esir aldığı bir hadisedir. Bahreyn Karmâtîlerin reisi Ebû Tâhir el-Cennâbî, Abbasilerin kontrolündeki Basra'ya hareket ederek oradakileri kılıçtan geçirmiştir. O, aradan çok zaman geçmeden Mekke'den dönen hac kafilelerine saldırmıştır. Ebû Tâhir el-Cennâbî, Hubeyr'de Bağdatlı hacıların bulunduğu ilk kafiledeki birçok Müslümanı şehit etmiş ve diğer kafilelere doğru hareket etmiştir. Ebû Tâhir'in sebebiyet verdiği bu olayda Ebû Muhammed el-Cerîrî de vardır ve orada şehit edilmiştir. Zehebî, Siyeru a'lâmi’n-nübelâ, 11/286; Ebü’l-Abbâs Muhammed b. İbrâhîm İbn Hallikan, Vefeyâtü'l-a'yân ve enbâ'ü ebnâ'i'z-zamân (Beyrut: Daru Sadr, 1971), 4/ 335; Ali Avcu, Karmatîlerin Doğuşu ve Gelişimi (Ankara Üniversitesi, Sosyal Bilimler Enstitüsü, Basılmamış Doktora Tezi, 2009), 214-215; Ayrıca bkz. Mustafa Öz, "Cennâbî Ebû Tâhir”, Türkiye Diyanet Vakfi İslâm Ansiklopedisi (İstanbul: TDV Yayınları, 1993), 7/372-373.

18. Kelâbâzî, et-Taarruf, 166.

19. bkz. Ebû Abdillâh Şemsüddîn ez-Zehebî, Târîhu'l-İslâm ve vefeyâtü'l-meşâhîr ve'l-a'lâm (b.y.: el-Mektebetü't-Tevfîkıyye, ts.), 23/404.

20. Zehebî, Târîhu'l-İslâm ve vefeyâtü'l-meşâhîr ve'l-a'lâm, 23/446.

21. Kelâbâzî, et-Taarruf, 166-167.

22. Bağdâdî, Târîhu Băğâd, 6/116. 
Buraya kadar Cerîrînnin hayatı hakkında bilgi vermeye çalıştık. Şimdi ise onun kendi döneminde hangi sûfîlerle görüştüğüne kısaca temas edeceğiz.

Ebû Muhammed el-Cerîrî hem hocası hem de yaşadığı muhit sebebiyle diğer sûfîlerle irtibat halindedir. Cüneyd-i Bağdâdî ile arasındaki yakınlığ 1 muhtemelen hocası ve aynı zamanda dayısı Serî es-Sakâtî (ö. 251/865) ile başlamıştır. Zira kaynaklar, Cerîrînnin Serî es-Sakâtî ile ilişkisinin bulunduğunu haber vermektedir. ${ }^{23}$ Sakâtî dışında, kendisinin meclisinde bulunduğu Sehl b. Abdullah et-Tüsterî, Cerîrînnin yetişmesinde etkili olsa gerektir. ${ }^{24}$ Buna mukabil Cerîrînin sohbetlerinde bulunan ya da arkadaşlık ettiği sûfîler de vardır. Ebû Abdullah Muhammed b. Hafif (ö. 371/982), Ebu'l-Hasen el-Bûşencî (ö. 348/959), Ebu'l-Abbas ed-Dineverî (ö. 340/951), Ebu'l-Abbas b. Mesrûk (ö.298/910), Rüveym b. Ahmed (ö. 303/915) ve İbn Ata (ö. 309/922) bunlar arasındadır. Zikredilen sûfîlerle görüşmenin merkezinde Cüneyd-i Bağdâdî yer alır. Zira Bağdat'taki sûfîlerin büyük bir kısmı Cüneyd'in sohbetlerine katılmışlardır. Cerîrî’nin de bu meclislerde bulunduğunu söylemek mümkündür. Buna ilaveten Cüneyd'in vefatından sonra yerine Cerîrî’nin geçtiği bilindiğine göre bölgedeki sûfîler, Cerîrînin meclisine katılmış olmalıdırlar.

Cerîrî̀nin yukarıda saydığımız sûfîlerle irtibatı çeşitli şekilde meydana gelmiştir. Konuya dair üç örnek verilebilir. Birincisi, Cüneyd-i Bağdâdînnin meclisinde İbn Mesrûk ve başkalarının da bulunduğu bir hadisedir. Konu vecdle ilgilidir. Okunan kasidenin ardından Cüneyd-i Bağdâdî ve Cerîrî hariç mecliste bulunanların hepsi vecd sebebiyle harekete geçmişlerdir. Cerîrî ve Cüneyd'în arasında geçen konuşma bize her iki sûfînin harekete geçmeme sebeplerini vermektedir. ${ }^{25}$ Esasında zikredilen konu, bize sûfîlerin aynı mecliste bir araya geldiklerinde bireysel farklılıkların tasavvufi konulara da yansıdığını göstermektedir. İkincisi, "kurtuluşa erenler"in kim olduklarına yönelik Cüneyd-i Bağdâdî, Rüveym, Cerîrî ve İbn Atâ’nın görüşlerini anlatmaktadır. İlk önce Cüneyd, "kurtuluşa erenler” hakkında Kur'ân'dan delil getirerek fikrini belirtir ve ardından Rüveym, Cerîrî ve İbn Atâ görüşlerini serdederler. ${ }^{26}$ Bir mecliste, Cüneyd-i Bağdâdî̀nin me-

23. Zehebî, Siyeru a'lâmi’n-nübelâ, 11/286; Zehebî, Târîhu'l-İslâm ve vefeyâtü'l-meşâhîr ve’la'lâm, 23/404.

24. Sülemî, Tabakât, 154; Kuşeyrî, er-Risâletüll-Kuşeyriyye, 180.

25. Kuşeyrî, er-Risâletü'l-Kuşeyriyye, 245-246.

26. Kuşeyrî, er-Risâletü'l-Kuşeyriyye, 324. 
seleyi açıp etrafındaki sûfîlerin kendilerine ait fikirlerini ortaya koyması önemlidir. Zira bu durum sûfîlerin birbirlerinden haberdar olduklarını ve aralarında müzakere yaptıklarını gösterir. Üçüncü örnek ise sûfîlerin mektuplaşmalarıyla ilgilidir. Amr b. Osman el-Mekkî (ö. 297/910) Bağdat'ta bulunan sûfîlere bir mektup gönderir. Mektup okunduğunda ismi geçmeyen diğer sûfîlerin yanında Cüneyd-i Bağdâdî, Cerîrî ve Ebû Bekir Şiblî (ö. 334/946) de bulunmaktadır. Mektup okunduktan sonra üç sûfî de kanaatlerini açıklamışlardır. Esasında bu tarz mektuplaşmalar sûfîlerin adetlerindendir. Onlar yaşadıkları hallerle ilgili bir hususu danışmak için yazdıkları gibi kendilerine yöneltilen sorulara cevap mahiyetinde de mektup kaleme almışlardır. ${ }^{27}$

\section{Cüneyd-i Bağdâdî ile İlişkisi}

Cüneyd-i Bağdâdî̀nin “Bağdat tasavvuf teşekkülünde” önemli bir yeri olduğu gibi vefatından sonra da tasavvuf düşüncesinde merkezi bir konuma sahipliği zikredilmektedir. ${ }^{28}$ Cüneyd-i Bağdâdînnin bu konumu “Tâvûsu'l-Ulema, Seyyidü't-Tâife, İmâmü'l-Eimme, Lisânü'l-Kavm, A'bedü'l-Meşâyih ve Sultânü'l-Muhakkıkîn" gibi ifadelere yansımıştır. ${ }^{29}$ Bağdat’taki öğrencilerinden biri de Cerîrî̀dir. Cerîrînnin Cüneyd-i Bağdâdî ile ilişkisi hoca-öğrenci ya da mürit-mürşit ilişkisinin hicri üçüncü asırda Bağdat'taki karşıllı̆̆ıdır. Kaynaklarda, onu Cüneyd-i Bağdâdînnin terbiye ettiği, önde gelen müridi ve hatta onun "sırdaşı" olduğu geçmektedir. ${ }^{30}$ Muhtemeldir ki yetişme sürecinde Cüneyd-i Bağdâdî ondaki yetkinliği görmüş ve ona, mahiyeti kaynaklarda geçmeyen sırlarını vermiştir. Cüneyd'in kendisine ayrı bir "değer vermesi, saygı göstermesi ve hürmet etmesi” Cerîrî̀ye karşı özel tavrını açıklaması bakımından önemlidir. ${ }^{31}$ Aynı şekilde Cerîrî̀nin hac dönüşü Cüneyd'i ziyaret etmek istemesi

27. Ebû Nasr es-Serrâc, el-Lüma' (Kahire: Dâru'l-Mukattam li'n-Neşr ve't-Tevzî', 2018), 257; Örnek için bkz. Hamid Algar, "Mektûbât" Türkiye Diyanet Vakfi İslâm Ansiklopedisi İstanbul: TDV Yayınları, 2004).

28. Ahmet T. Karamustafa, Tasavvufun Oluşumu (İstanbul: Bilgi Üniversitesi Yayınları, 2017), 27. 29. Süleyman Gökbulut, “Tasavvuf Tarihinde Cüneydî Çizgi”, Dokuz Eylül Üniversitesi İlahiyat Fakültesi Dergisi 36 (2012), 172.

30. Zehebî, Siyeru a'lâmi’n-nübelâ, 11/286; Sülemî, Tabakât, 154; Hücvirî, Keşfu'l-mahcûb, 211. 31. Bağdâdî, Târîhu Bağdâd, 6/116; Ebü’s-Safâ Salâhuddîn es-Safâdî, el-Vâfî bi'l-vefeyât (Beyrut: Dâru İhyai-Turas, 2000), 7/247; Sülemî, Tabakât, 154; Kuşeyrî, er-Risâletü’l-Kuşeyriyye, 180. 
aralarındaki ilişkiyi anlatması bakımından kayda değerdir. Serrâc'ın ifadesine göre o, hacdan döndükten sonra hocası kendisini ziyaret için yorulmasın diye hemen ona gitmek istemiştir. Öğle namazının ardından hocasını görür. Cüneyd'e onun yorulmaması için gelme niyetinin bulunduğunu söyleyince Cüneyd ona, "bu ziyaret senin hakkın, niyet ettiğin şey ise senin büyüklüğün"32 diye cevap verir. Vakıa, onun Cüneyd-i Bağdâdî̀ye gösterdiği hürmetini ve edebini ortaya koymaktadır.

Cerîr̂̂’nin yetişmesinde Cüneyd-i Bağdâdînnin etkisi büyüktür. Mevcut rivâyetlerden anlaşıldığı kadarıla onun Cüneyd-i Bağdâdı̂’nin halifelerinden biri olduğu söylenebilir. Zira hem Cüneyd-i Bağdâdî’nin terbiyesinde yetişmiş hem de vefat edince onun yerine geçmiştir. Cerîrînnin Cüneyd-i Bağdâdî’nin halifesi olduğuna dair iki husustan bahsedilebilir: Birincisi Cüneyd-i Bağdâdî hayattayken kendisinden sonra halifelik için Cerîrî̀ye işaret etmesidir; ikincisi Cerîrînnin ilmi ve tasavvufi şahsiyetinin ön plana çıkarılmasıdır.

Cüneyd-i Bağdâdî hayattayken zaman zaman Cerîrî̀yi kendisinden sonra halifesi olduğuna işaret etmiştir. Cüneyd-i Bağdâdî̀nin vefatı sırasında cereyan eden şu konuşma bize Cerîrînin halifeliği konusunda bilgi vermektedir: "Cüneyd-i Bağdâdî̀ye vefatı anında "senden sonra kimi makamina yerleştirelim," diye sorulduğunda Cüneyd, Ebû Muhammed Cerîrî̀ye işaret etmiştir. ${ }^{33}$ Konuya dair bir başka rivâyet de Tezkiretül-Evliyâ da geçmektedir. Rivâyete göre Cüneyd, Cerîrîyi kastederek "benim veliahtım odur" demiştir. ${ }^{34}$ Hücvîrî ise Cüneyd'in şu sözüne yer vermektedir: "Ey Cerîrî, müritlerime edep ögret, riyâzetlerine nezaret et." ${ }^{35}$ Cüneyd'in ifadesi doğrudan bir işaret ifade etmese de kendisinden sonra yerine gelecek kimseyi ima etmektedir. Cerîrînnin Cüneyd-i Bağdâdî vefat ettikten sonra onun makamına geçtiğini doğrudan Cüneyd'in söylemlerinden değil, onun tasavvufî ve ilmî yetkinliğine bağlayan ifadelerden anlamaktayız. Hem İslâm tarihi hem de tasavvuf kaynaklarında Cerîrînnin "hâlinin tamlı̆̆ı ve ilmî yetkinliği sebebiyle" Cüneyd-i Bağdâdî’nin yerine geçtiği

32. Ebû Câfer Nasr es-Serrâc, el-Lüma' (Kahire: Dâru'l-Mukattam li’n-Neşr ve’t-Tevzî', 2018), 230. Kuşeyrî̀deki rivâyette Cüneyd'in Cerîrî̀nin ziyaretinden sonraki günde sabah namazına gidip Cerîrî’yi ziyaret etmesi vardır. Kuşeyrî, er-Risâletü'l-Kuşeyriyye, 532.

33. Bağdâdî, Târîhu Bağdâd, 6/116.

34. Attâr, Tezkiretü'l-evliyâ, 523.

35. Hücvirî, Keşfu'l-mahcûb, 211. 
yönünde açıklamalar mevcuttur. ${ }^{36}$ Bütün bu açıklamalar bize Cerîrînnin Cüneyd-i Bağdâdînnin halifesi olduğunu ortaya koymaktadır. Buna ilaveten Cerîrî̀nin Cüneyd-i Bağdâdî'den sonra on beş yıl onun makamında görev yaptığı da söylenebilir.

Cerîrî̀nin Cüneyd-i Bağdâdî’nin vefatı sırasında yanında bulunduğu kaynaklarda geçen bilgilere istinaden anlaşılmaktadır. Muhtemelen hocasını yalnız bırakmak istemeyen Cerîrî kendisine düşen görevi yerine getirmek istemektedir. Onun ifadesine göre Cüneyd-i Bağdâdî ömrünün son anlarında hep secde halindeydi. Kendisine dinlenmesini söyleyen Cerîrî̀ye, "kendisine gerekli ya da faydal şeyi yaptığın"37 belirten Cüneyd "sûfî, ibnü'l-vakt”tir ifadesinin canlı örneği olmuştur. Cerîrî ahirete secde halinde giden Bağdâdî̀ye şahitlik etmiştir. Dolayısıyla onun Cüneyd ile ilişkisi onun vefatına kadar süren ve kopmayan bir ilişki şeklinde kendisini göstermektedir.

\section{Görüşleri}

\subsection{Nefs Hakkındaki Görüşleri}

Tasavvufta nefs, sıklıkla kullanılan kavramların başında gelmektedir. Kelime olarak "zat, öz, rûh, beden" ${ }^{\text {"3 }}$ anlamlarına gelir. Tasavvufta ise kelime anlamının dışında "kötülüğün kaynağı” manasında kullanılır. Hem Kuşeyrî hem de Hücvîrî "sûfîlerin nefs kelimesinden kasttlarının onun kötü fiillerin kaynăğ olduğudur," diye belirtmektedirler. ${ }^{39}$ Nefsin, kötülügün kaynağı kabul edilmesi sebebiyle ondan kaçınılması ve onun terbiye edilmesi gerekir. Sûfîler bunun için "sülûk" yöntemleri geliştirmişlerdir. Sülûk “insanı Hakk’a ulaştıran tavır, amel, ibâdet, fiil, hareket ve davranış tarzları" ${ }^{40}$ anlamında kullanılmaktadır.

36. Sülemî, Tabakât, 154; Ebü'l-Kâsım et-Teymî, Siyeru selefi's-sâlihîn (Riyâd: Dâru'r-Râyeti li’n-Neşri ve't-Tevzî, ts.), 1258.

37. Serrâc, el-Lüma', 236; Ebü'l-Hüseyn İbn Ebû Ya'lâ, Tabakätü'l-Hanâbile (Beyrut: Dârü'lMarife, ts.), 1/129; Ebû Nasr Tâceddîn es-Subkî, Tabakātüşs-Şâfi'iyyeti'l-kübrâ (b.y.: Hicru li't-Tibâati ve'n-Neşri ve't-Tevzî, 1413), 2/266.

38. Ebu'l-Fazl Muhammed İbn Manzûr, Lisânü'l-Arab (Kahire: Dâru'l-Maârif, ts.), 4500-4501. 39. Kuşeyrî, er-Risâletü'l-Kuşeyriyye, 290; Hücvirî, Keşfu'l-mahcûb, 259-260. 40. Süleyman Uludağ, "Sülûk" Türkiye Diyanet Vakfi İslâm Ansiklopedisi (İstanbul: TDV Yayınları, 2010), 38/127. 
Cerîrînnin nefse dair görüşlerini iki şekilde ele almak mümkündür. Birincisi, nefse dair uyarıları ve nefsin kötülüğüne yönelik düşüncesidir. İkincisi ise sistematik bir şekilde ele almasa da nefsi eğitmeye yönelik fikirleridir. Cerîrî nefsin kötülüğünü kabul eder ve "nefs kimi ele geçirirse o şehvetinin esiri olur, hevasina hapsolur" ${ }^{\text {"11 }}$ diyerek hem bu konuya hem de nefsin hâkimiyetinin bireyde ortaya çıkardığı sonuca dikkat çeker. Onun bu görüşü ilk dönem sûfîlerin nefse dair geliştirdiği düşünceye uygundur. Hatta nefsin bu yönüne karşı çıkmayı en değerli ibâdet kabilinden değerlendirenler vardır. ${ }^{42}$ Nefse karşı ortaya çıkan bu düşüncelerin temelinde nefse uymanın Hakk'tan uzaklaşmayla aynı anlamda kullanılmasının yattığı söylenebilir.

Cerîrî nefsin, insanın farkına varmadan güzel davranışlarında dahi ortaya çıabileceğini düşünmektedir. $\mathrm{O}$, "safâ halinde safâyı mülahaza etmek cefadır, zira onda insan tabiatının karışıllğı ve kişinin fiilini görme durumu vardır"43 diyerek bu durumu izah eder. Bireylerin kendi eylemlerine bakmasını, kendini beğenme eğilimi kapsamında ele almak mümkündür. Ayrıca kendi makamını değerli görme duygusuyla da ilgi kurulabilir. Esasında bu hususu, kişinin eriştiği hal ya da makamı Hakk'ın nasip ettiğini ortaya koyacak düşüncede ve tutumda bulunmamasıdır diye zikretmek mümkündür.

Cerîrî̀nin nefse dair çizdiği bu portre dışında onun terbiyesine yönelik düşüncelerine de değinmek gerekmektedir. Nefsin terbiyesinde ortaya çıkan hususlar önce teklife taalluk edenler sonrasında ise nafileler, mücâhede ve riyazete giren unsurlardır. Ahlaklanmayı da ifade eden bu süreç hem nübüvvete ittibayı gerekli kılmaktadır hem de bilgiye götüren bir yöntemdir. ${ }^{44}$ Cerîrî, kendisinin de içinde bulunduğu tasavvufun zemininin ne olduğunun tespitini yapar. Ona göre bu yolda iki esas vardır: "Nefsin Allah'ın murâkabesine alıştırılması ve ilmin zâhirde kaim olmastdır." ${ }^{45}$ Cerîrînnin ifadesindeki bu iki husus kişinin dünya hayatında nasıl bir tavır takınması gerektiğini ortaya koymaktadır. Dünyevi işlerin ilme uygunluğu her inanan kişiden beklenilen bir tavırdır. Nefsi murakabeye

41. Kuşeyrî, er-Risâletül'-Kuşeyriyye, 180; Sülemî, Tabakât, 155; Attâr, Tezkiretü’l-evliyâ, 524.

42. Kuşeyrî, er-Risâletü'l-Kuşeyriyye, 391.

43. Serrâc, el-Lüma', 351.

44. bkz. Ekrem Demirli, İslâm Metafiziğinde Tanrı ve İnsan (İstanbul: Kabalcı Yayınları, 2012), 152-153.

45. Kuşeyrî, er-Risâletü'l-Kuşeyriyye, 450. 
alıştırmak ise sûfîlerin dikkat çektiği noktalardan birisidir ve umumun bu şekilde davranması kolay değildir. Cerîrî de muhtemelen tasavvufî yönü bu cümleyle ortaya koymak istemektedir.

Kişinin nefsini murakabeye alıştırması, onun düşüncesinde ahiretin her şeyden önce geldiğini ifade eder. Tasavvuf, dünya-âhiret konusunda ahiret lehine taraftır ve nefs terbiyesinin gayelerinden biri de budur. Cerîrî̀nin söylemlerinde bu hususa yönelik izler bulunmaktadır. Mâsivâdan uzaklaşılmasındaki acilliğe yaptığı vurgu esasında dünyayla kurulacak ilişkiye dair bir uyarı niteliğindedir. O şöyle söyler: "Mâsivâdan uzaklaşma ilmini elde etmeye hemen koyulmak bir vesiledir." ${ }^{46}$ Cerîrî bununla bağlantılı kabul edilebilecek "kurra" tanımı yapmaktadır. Yaptığı tanımda dikkat çeken husus, âhiret ve dünya karşısında takınılan tavır olarak kendisini belirtir. O, kurray1 "âhirete talip olan, tüm gayretini ahiret için sarf eden, dünyadan ve dünya ile meşgul olmaktan yüz çeviren kimse" ${ }^{\text {"47 }}$ diye tarif eder.

Nefsin dünyaya dalmamasına yönelik ifadelerin ardından Cerîrî, onun dikkatini âhirete yönlendirmek için bazı hususlara değinmektedir. Cerîrî̀nin zikrettikleri hususen bir başlık altında mevcut olmasa da nefsin terbiyesine yönelik söylendiği kabul edilebilir. Zira tasavvuf tarihindeki nefsin eğitilmesine yönelik temas edilen unsurlarla benzerlik gösterdiğini ifade etmek mümkündür. Hem Sehl b. Abdullah Tüsterî (ö. 283/896) hem de sûfî müelliflerden Ebû Tâlib el-Mekkî (ö. 386/996) zikredilen konuları ele almaktadırlar. Onlar nefsin eğitilmesi konusunda "az yeme, az uyuma, az konuşma ve halvet" ${ }^{48}{ }^{40}$ emli bir yeri bulunduğuna dikkat çekmektedirler.

46. Sülemî, Tabakât, 155.

47. Sülemî, Tabakât, 155. Cerîrî benzer bir durumu hadis müzakeresi için toplanıldı̆̆ında ortaya koymaktadır. Burada esas konu ilmin müzakeresinde ortaya çıkan ahlaki zafiyetle alakalıdır. O şöyle söyler: "Müzakere sebebiyle oturmada fayda yoktur; nasihatleşmek için oturmada da fayda bulunmaktadır." Bu konu o dönemin hadis rivâyet etmedeki maksada karşı sûfîlerin takındıkları tavırla alakalı gözükmektedir. Seri es-Sakatı, Fudayl b. Iyaz gibi sûfîlerin hadis rivâyet etmeye dair bazı olumsuz yaklaşımları mevcuttur. Cerîrî̀nin yukardaki sözünde geçen "müzakere" ise Melchert'a göre doğrudan hadislerin müzakere edildiği yer olarak değerlendirilmektedir. Bunun doğru olma ihtimali olabilir; ancak Cerîrî bu müzakere yapılan yerlerden ziyade konunun kişide ortaya çıkardığı ahlaki problemlere dikkat çekmiş de olabilir. Zira "müzakere yani hafıza yarışı sûfîler tarafından bir gösteri ve yarış vesilesi olarak itici ve rahatsız bulunuyor olması büyük ihtimaldir.” Bkz. Tûsî, el-Lüma', 203. Christopher Melchert, Sünnî Düşüncenin Teşekkülü: Din-Yorum-Dindarlık, çev. Ali Hakan Çavuşoğlu (İstanbul: Klasik Yayınları, 2018), 320-322. 48. Ebû Tâlib el-Mekkî, Kûtül-kulûb fî muâmeleti'l-mahbûb ve vasfu tarîki'l-mürîd ilâ makâmi't-tevhîd (Beyrut: Dâru Sadır, ts.), 1/201-201. 
Cerîrî de Tüsterî’nin ve Mekkî’nin belirttiği konuların hepsine ayrıntılı yaklaşmasa da uzlet, inziva ve az yemeyi ön plana çıkarmaktadır. Seyid Şerif Cürcânî (ö. 816/1413) uzleti, “bir köşeye çekilmek ve münasebetlerini kesmek yoluyla insanlardan uzaklaşmaktı" "49 diye tanımlar. Süleyman Uludağ ise "tasavvufta bir zâhidin veya sûfinin Allah'a daha fazla ve daha ihlâsl şekilde ibadet etmek için dünyevî işlerden kendini soyutlayarak bütün varlı̆̆ıla Hakk'a yönelmesi" ${ }^{50}$ şeklinde uzleti açıklamaktadır. Cerîrî uzlete dair bir tanım ortaya koymaktadır. Onun uzlete çizdiği şema, toplumdan uzaklaşmak yerine topluma dahil olup Hakk'la birlikte yaşamaktır. İnsanlarla birlikte yaşamanın bazı zorluklarının bulunduğunun farkındadır ancak bu zorluklarla birlikte Hakk’a yaklaşmayı "uzlet” tanımı içerisinde ele almaktadır. O uzlete dair şunu söyler: "Uzlet kalabalı̆̆a girip sırrın onlarla rekabet etmekten koruman, nefsinin günahlardan uzaklaşması ve sırrının Hakk'a bağlı olmasıdır." ${ }^{51}$ Cerîrî’nin uzlet hakkındaki düşüncesi halvet-der encümen düşüncesini anımsatmaktadır. Dolayısıyla bu kavram için ifade edilen anlamın kökenini onun düşüncesinde bulmak mümkündür. ${ }^{52}$ Cerîrî’nin uzlet dışında inziva içinde bir tanım yaptığı bilinmektedir. Bu tanımda o, hayatın ya da insanların getirdiği sıkıntılardan uzaklaşmayı salık vermektedir. Dolayısıyla uzlet düşüncesiyle paralellik arz ettiğini söylemek pek mümkün değildir. Cerîrî inziva için şunu söyler: "Meşakkatlerden uzaklaşı sı sırı korumaktır."

Cerîrî uzlet ve inziva konusuyla birlikte az yemeyle ilgili nefsi eğiten yönteme de değinmektedir. O, konuyu ele aldığı yerde “din, iman ve beden sağlığı” hakkında bilgi verir ve bu üç unsurun korunmasına yönelik çözümler sunar. Bahse konu çözümler “iktifâ, ittikâ ve ihtimâ” kavramlarıyla anlatılır. İhtimâ, nefsin eğitilmesiyle gündeme gelir. Cerîrî̀nin düşüncesinde gerektiği kadar yeme ve içmeyi ihtiva eden bu kavram

49. Seyyîd Şerîf Cürcânî, Ta'rîfât: Tasavvuf Istılahları, çev. Abdülaziz Mecdî Tolun (İstanbul: Litera Yayıncılık, ts.), 111.

50. Uludağ, "Sülûk”, 38/127.

51. Kuşeyrî, er-Risâletül-Kuşeyriyye, 315.

52. bkz. Süleyman Uludağ, "Halvet Der-Encümen” Türkiye Diyanet Ansiklopedisi (İstanbul: TDV Yayınları, 1997), 15/387-388.

53. Attâr, Tezkiretü'l-evliyâ, 525. Cerîrî halvet konusuna onun tanımını yapmak yerine halvette nasıl davrandığına yönelik açıklamalarıyla değinmektedir. O, halvetteki edebini şu şekilde açıklamaktadır: "Yirmi yıldır halvetteyken oturduğum zaman ayaklarımı uzatmadım. Allah’la birlikteyken ona karşı güzel edep göstermek en evla şeydir. bkz. Bağdâdî, TârîhuBăgdâd, 6/116; Kuşeyrî, er-Risâletü'l-Kuşeyriyye, 695; Attâr, Tezkiretü’l-evliyâ, 523. 
aynı zamanda riyazetle benzer anlamda kullanılmaktadır. Dahası Cerîrî "gereksiz yeme içmeden kaçan kimsenin nefsinin riyazet üzere" olacağ1nı söyler. Ona göre bu durum "fitratın/tabiatın itidal üzere bulunması" anlamına gelir. Esasında nefsin terbiyesi hem ahlâki bir boyutu hem de bireyin günlük yaşantısında dengeyi ortaya çıkarmaktadır. Cerîrî̀nin ifadesi şu şekildedir:

"Dinin bekâsı, imanın devamı ve beden sağlığı şu üç şeyle mümkün olur: İktifâ, ittikâ ve ihtimâ. Allah'la yetinenin kalbi güzelleşir; yasaklanan şeylerden sakınanın yaşantısı dosdoğru olur, lüzumsuz yiyip içmekten sakınanın da nefsi riyazet üzere bulunur. Allah'la yetinmenin meyvesi mârifetin saf olması, takvâ sahibi olmanın semeresi ahlâk güzelliği, riyazet yapmanın neticesi de tabiatın itidal üzere bulunmasıdır." ${ }^{54}$

Bütün bu söylenenlerin ardından Cerîrî, nefsin eğitilmesinden sonra ortaya çıkacak güzel ahlakı, tasavvufun neliğine yönelik tanımlarında görüleceği üzere tasavvufla eş anlamda kullanmaktadır. Dahası Cerîrî tasavvufu, "güzel ahlakın içinde olma" diye tarif ederek umum için bir çözüm olarak sunduğunu düşünebiliriz. Zira tanımın devamında "kötü ahlaktan uzak durma" ${ }^{55}$ bulunmaktadır. Cerîrî, güzel ahlak için tasavvufu öne çıkardığı gibi bir davranışın yetkin hale gelmesi ya da yetkinlikle ortaya çıkması için de tasavvufu gündeme getirir. İnsan davranışlarının yetkinliği hem niyetle hem de eylemle kendisini gösterir. Cerîrî, tasavvufu "halleri murakabe etmek ve edebe sarılmak" ${ }^{66}$ diye tarif eder ve bireylerden sadır olacak davranışların hem yetkinliğini hem de bu yetkinliği sağlayacak bilincin sürekliliğine vurgu yapar. ${ }^{57}$ Dolayısıyla Cerîr̂̀’nin nefsin terbiyesine yönelik değerlendirmeleri olsa da tasavvufu çözüm olarak değerlendirmektedir.

\subsection{Marifet Hakkındaki Görüşleri}

Marifet kelime olarak "bilmek, tanımak, şüphe olmaksızın bilmek, bilgi, ilim” anlamlarında kullanılmaktadır. Sûfîler marifetin neliğine

54. Hücvirî, Keșfu'l-mahcûb, 211; Sülemî, Tabakât, 156; Attâr, Tezkiretü’l-evliyâ, 525.

55. Kuşeyrî, er-Risâletü’l-Kuşeyriyye, 585.

56. Kuşeyrî, er-Risâletü’l-Kuşeyriyye, 589.

57. bkz. Yakup Pekdoğru, Erken Dönem Tasavvuf Klasiklerinde Marifet: 4-5. Yüzylllar (Ankara Üniversitesi, Sosyal Bilimler Enstitüsü, Basılmamış Doktora Tezi, 2020), 168-173. 
yönelik açıklama yapmışlardır ancak bu tanımlar üzerinde bir ittifakın bulunduğunu söylemek mümkün değildir. ${ }^{58}$ Çağdaş tasavvuf araştırmacılarından Uludağ, marifeti şu şekilde tanımlar: "Sûfîlerin ruhani halleri yaşayarak, manevi ve ilahi hakikatleri tadarak elde ettikleri bilgi, irfan." ${ }^{\text {. }}$ Sûfîlerin eriştiği marifet ise ilk dönemlerden itibaren "keşf, müşahede, feth, firaset, yakîn" gibi kavramlarla ifade edilmiştir. ${ }^{60}$

Cerîrî de marifet hakkında görüş bildiren sûfîler arasındadır. Onun marifete dair söylemlerini üç başlık altında değerlendirmek mümkündür. Bunlar; marifete erişme yöntemi, marifetin Kur'ân'ın anlamıyla kurulan ilişkisi ve Cüneyd-i Bağdâdî’nin Cerîr̂̂’nin marifetteki yetkinliğini ortaya koyan düşüncesidir.

Marifete erişmek, fikıh ve kelam gibi disiplinlerin bilgiye ulaşma yöntemlerinden farklıdır. Nefsin terbiyesi ya da bütünüyle sülûk marifete erişmek için gündeme gelmektedir. ${ }^{61}$ Cerîrî de sülûkun bütün yönlerine yer vermese de marifete erişmek için “takvâ ve murâkabe” yi ön plana ç1karmaktadır. O şöyle söyler: "Kim Allah ile olan ilişkisini takvâ ve murâkabe üzerine kurmazsa keşfve müşâhedeye ulaşamaz." Cerîrî̀nin ifadesi hem yöntemi öz bir şekilde açılamaktadır hem de marifete erişmede bir ilke olarak değerlendirilebilir. ${ }^{63}$ Benzer bir hususu amelle marifete götüren süreci anlattığı yerde fikıhtaki "asl" ve füru” kavramlarından örnek vererek açıklamaktadır. Ona göre "aslı müşâhede makâmına ulaştırmak ancak füru ile mümkün" dür. ${ }^{64} \mathrm{Bu}$ da marifete erişmede yönteme değinen bir açılama olarak gündeme gelmektedir.

58. bkz. Pekdoğru, Erken Dönem Tasavvuf Klasiklerinde Marifet, 187-200.

59. Süleyman Uludağ, Tasavvuf Terimleri Sözlüğ̈̈ (İstanbul: Kabalcı Yayınevi, 2012), 236; Ayrıca bkz. Ethem Cebecioğlu, Tasavvuf Terimlerive Deyimleri Sözlüğü (Ankara: Otto Yayınları, 2014), 318-319.

60. Süleyman Uludağ, “Keşf” Türkiye Diyanet İslâm Ansiklopedisi (İstanbul: Türkiye Diyanet Vakfı Yayınları, 2002), 25/315.

61. Bkz. Fazlurrahman, İslâm, çev. Mehmet Dağ - Mehmet Aydın (Ankara: Ankara Okulu Yay., 2016), 131; Abdullah Kartal, Tasavvufun Oluşumu: Şeriat-Hakikat İlişkisi (Bursa: Emin Yayınları, 2015), 60.

62. Serrâc, el-Lüma', 357; Kuşeyrî, er-Risâletü'l-Kuşeyriyye, 320.

63. Benzer bir ifade Ebu Ali Dekkak'tan da gelmektedir. bkz. Kuşeyrî, er-Risâletü’l-Kuşeyriyye, 306. Marifete erişmede sülûka giren hususlar yetkin bir şekilde yerine getirilse de nihayetinde marifeti zorunlu olarak ortaya çıkartmayacağı sûfîler tarafından vurgulanmaktadır. Hakk'ın iradesi bu konuda kendisini göstermektedir. Örneğin Hücvîrî şunu söyler: "Mücahede kulun fiilidir müşahede Hakk'ın mülküdür.” Bkz. Hücvîrî, Keşfu'l-Mahcûb, 268.

64. Kuşeyrî, er-Risâletü'l-Kuşeyriyye, 181; Sülemî, Tabakât, 157; Attâr, Tezkiretü’l-evliyâ, 525. 
Sûfîler, marifetle Kur’ân'ın anlamı arasında bir ilişki kurmaktadırlar. Kur'ân'ın anlamına ulaşmak için müfessirler "rivâyet" ve "dirâyet" usulünü geliştirmişlerdir. ${ }^{67}$ Sûfîler de Kur'ân'ı anlama gayreti içinde bulunmuşlar ve onların geliştirdiği usule "işârî"

Cerîrî nefsini terbiye etmeyenin Hakk'in kelamından bir tat alamayacağını belirtir ve ona manevî fayda sağlamayacağını zikreder. Buna o, "yeryüzünde haksız şekilde kibirlenenleri âyetlerimizden menedeceğim" 69 âyetini delil getirmektedir. Sülemî de aynı ayetten hareketle bu kimselerin "Hakk'ın kelammı anlayamayacaklarmı" belirtir. Zira her iki sûfîye göre nefs, Kur'ân'ı anlamaya engel bir perdedir. Bu perde sebebiyle hem idrakten hem de zevkten mahrum bırakılmışlardır. ${ }^{70}$ Dolayısıyla Kur'ân'ın anlamına ulaşmak rivâyetlerden ya da entelektüel bir gayretten öte ahlaklanma sürecinin bir sonucudur. ${ }^{71}$ Buna ilaveten Cerîrî "Rabbâniler olun"72 âyetinin anlamının şu olduğunu söyler: "Allah'tan işitin ve Allah ile söyleyin." ${ }^{73} \mathrm{O}$, Hakk'tan işitme imkanının bulunduğunu kabul eder ve

65. Rivâyet tefsiri: "Buna me’sur veya nakli tefsir de denilir. Seleften nakledilmiş eserlere dayanan tefsirdir. Diğer bir deyimle, rivâyet tefsiri, bazı âyetleri beyan ve tafsil etmek için, bizzat Kur'ân'daki başka âyetlerle, Hz. Peygamber'in (a.s.) sahabenin sözleriyle açıklanışı şekline denir. Hatta bazıları buna tabiunun sözlerini de ilave eder." bkz. İsmail Cerrahoğlu, "Tefsir Usûlü”, Türkiye Diyanet Vakfi İslâm Ansiklopedisi (Ankara: TDV Yayınları, 2014), 238.

66. Dirayet tefsiri: “Buna re’y ve ma’kul tefsir de denilir. Rivâyetlere munhasır kalmayıp dil, edebiyat, din ve çeşitli bilgilere dayanılarak yapılan tefsirlerdir. Burada bahsettiğimiz re'yden maksat ictihattır." Cerrahoğlu, Tefsir Usûlü, 230.

67. Cerrahoğlu, Tefsir Usûlü, 289-311; Halis Albayrak, Tefsir Usûlü (İstanbul: Şule Yayınları, ts.), 83-105.

68. İşari Tefsir: "Keşf ve ilhamla Kur'ân âyetlerinin bir kısmının veya tamamının yorumlandığ1 tefsirler de işârî (remzî) tefsir adını almıştır." bkz. Süleyman Uludağ, "İşârî Tefsir”, Türkiye Diyanet Vakfi İslâm Ansiklopedisi (İstanbul: TDV Yayınları, 2001), 23/424.

69. el-A'râf 7/146.

70. Kuşeyrî, er-Risâletü’l-Kuşeyriyye, 180; Sülemî, Tabakât, 155; Attâr, Tezkiretü’l-evliyâ, 524. Cerîrî bir başka ifadesinde şunu söyler: "İlahi hitabı dinlemeye engel olacak şeylerden kendini korumak bir lütuftur." bkz. Sülemî, Tabakât, 155.

71. bkz. Pekdoğru, Erken Dönem Tasavvuf Klasiklerinde Marifet: 4.-5. Yüzyıllar, 244-253; Ayrıca bkz. Ekrem Demirli, “Kuşeyrî̀den İbnü’l-Arabî’ye İşâri Yorumculuk Hakkında Bir Değerlendirme: İşarî Yorumdan Tahkîke Doğru Kur'ân-1 Kerim Yorumculuğunun Gelişimi”, Atatürk Üniversitesi İlahiyat Fakültesi Dergisi 40 (2013), 121-142.

72. Âli İmrân 3/79.

73. Kuşeyrî, er-Risâletü’l-Kuşeyriyye, 695. Cerîrî̀nin şu ifadesi marifet kapsamında değerlendirilebilir. Zira Hakk'tan bilgi almaya yönelik vurgu söylemin temel konusudur. Onun ifadesi şu şekildedir. Muhammed b. Davud der ki: “Cerîrînnin yanındaydık ve o şöyle dedi: “Aranızda Hakk Teâlâ memlekette yeni bir şeyi/olayı yaratmadan önce kendisine bunu bildirdiği bir kimse var 
marifete dair önceki düşünceleri dikkate alındığında Hakk'a yaklaştıkça bu imkanının artacağı da ifade edilebilir.

Cerîrînnin marifetle olan ilişkisine Cüneyd-i Bağdâdî’nin düşüncesini aktararak konuyu bitirebiliriz. Cüneyd-i Bağdâdî, Cerîrînnin mürşididir ve aynı coğrafyada yaşadıkları için beraber vakit geçirme imkanları daha fazladır. Cerîrînin bulunmadığı herhangi bir mecliste Cüneyd, marifet ya da hakikat konusu açıldığında "bu meselelerin Cerîrînin alanı oldu$\breve{g} u n u$ "74 belirterek onun marifete dair kabiliyetini teslim etmiştir. Bu da bize Cüneyd'in öğrencisine karşı tavrını açıkladığı gibi her ikisinin de marifete yaklaşımlarını da izah etmektedir.

\subsection{Diğer Meseleler Hakkındaki Görüşleri}

Bu başlık altında Cerîrînnin düşüncelerini toplu bir şekilde ele alacağız. Ancak konuya başlamadan önce şunu belirtmekte fayda görüyoruz. Cerîrînin kaynaklarda kaydedilen ifadeleri tekil cümleler halinde yer aldığ 1 için aralarında herhangi bir bağlam bulunmamaktadır. Bu sebeple biz de bunları ayrı başlıklar halinde incelemek yerine bir bütün halinde işlemeye çalışacağız. Cerîrînnin kaynaklarda münferid olarak serdettiği sabır, tevhid, ihlas, riya, şükür ve iman gibi meselelerle ilgili ifadeleri bulunmaktadır.

Hücvirî iman konusunda sûfîlerin iki kısma ayrıldığını söyler. İhtilaf edilen husus imanın "ikrar, tasdik ve amel” olup olmamasıdır. İçlerinde Cerîrînin de bulunduğu bir grup, imanın "ikrar, tasdik ve amel” olduğunu düşünmektedir. Burada Cerîrî’nin yer alması ilginçtir. Zira Hücvirî, Cerîrînnin hocası Cüneydi-i Bağdâdînnin ameli hariçte tutarak imanı “ikrar ve tasdik” olduğunu kabul edenler arasında zikretmektedir. Dolayısıyla Hücvirî̀ye göre hoca ve öğrencisi arasında iman gibi önemli bir konuda ihtilaf vardır. ${ }^{75}$ Esasında bahsedilen konu kelam tarihinde tartışılmıştır ancak sûfîler de bu konuda görüşlerini belirtmişlerdir. ${ }^{76}$ İman konusuyla ilgisi kurulabilecek “tevhid” düşüncesi de Cerîrînnin zikrettiği konular

mıdır?" diye sordu. Biz de "hayır” dedik. Cerîrî "Allah'tan bir şey bulamamış kalplere ağlayın" dedi. bkz. Kuşeyrî, er-Risâletü'l-Kuşeyriyye, 524-525.

74. Bağdâdî, Târîhu Bağdâd, 6/116.

75. Hücvirî, Keşfu'l-mahcûb, 350.

76. bkz. A. Saim Kılavuz, Anahatlarıyla İslâm Akâidi ve Kelâm’a Giriş (İstanbul: Ensar Yayınları, 2007), 35-48. 
arasındadır. Ona göre "tevhid ilmine delillerle vukûfiyet" gerekir. Aksi halde kişilerin bu meselede ayakları sağlam zemine basmaz. ${ }^{77}$ Cerîrî̀nin "sağlam deliller" diye zikrettiği hususu iki şekilde anlamak mümkündür: Birincisi, bu ilimle uğraşan ulemanın delillerinin sağlamlığı anlamına gelebilir ki dolayısıyla onları takip edenler de tevhid konusunda hataya düşmezler. İkincisi ise sûfîlerin sülûk neticesinde eriştikleri tevhide dair idraktir. Bu idrake ancak marifetle erişilebilir. ${ }^{78}$ Cerîrîye göre böylesi bir tevhidi de ancak "tevhid lisanı" tanımlayabilir. ${ }^{79}$

İman ve tevhidden sonra Cerîrî amel konusuna da değinmektedir. O, sadece amelin yerine getirilmesiyle elde edilecek menfaatin ya da kurtuluşun bulunmadığını zikretmektedir. Bu düşüncesine Hz. Peygamber' in (sav) "sizden hiçbirinizi ameli kurtarmaz" ${ }^{80}$ hadisine atıfta bulunmaktadır. Hatta o, "imdi korkulandan kurtarmayan bir şey, umulana nasil ulaştırır! Vuslata, yalnızca Allah’n lütfuna doğru bir şekilde bel bağlayanın ulaşması ümit edilir" ${ }^{\text {11 }}$ diyerek zikrettiği şeyi gerekçelendirmek ister. Cerîrî̀nin anlatmak istediği husus esasında her şeyi Hakk'ın yarattığı ve her şey Hakk'ın lütfuyla meydana geldiği düşüncesidir. Cerîrî ibadetlerle ilgili başka bir meseleyi kendisine yöneltilen soruya cevap vererek gündeme getirir. Soru şudur: "Kul ne zaman ibadet ve taatin yükünden kurtulur?" O, böyle bir yükten kurtulmanın imkânsız olduğu görüşündedir, hatta "yük artar"82 diyerek soran kişinin muhtemelen beklemediği bir cevap vermiştir. Cerîrî̀nin cevabından hareketle bazı çıkarımlar yapılabilir. Birincisi soruyu soranın ibahi bir eğilimi bulunabilir. İbadetin yükünden kurtulma, teklife taalluk eden hususların düşmesi şeklinde yorumlanabilir ki, sûfîlerin bu mevzuya yaklaşımları nettir. Sûfîler, hiçbir şekilde kulluk

77. Serrâc, el-Lüma', 376; Kuşeyrî, er-Risâletü'l-Kuşeyriyye, 84, 448. Cerîrî’nin Hakk'ın varlığ́na dair şu sözü onun alemden hareket ederek Hakk'ın varlığına delil getirmektedir: “Şu üç şey Allah’a en iyi şekilde delalet eder. Zahirdeki mülkü, mülkündeki tasarrufu ve her şeyi bütünüyle ihata eden kelamı.” bkz. Sülemî, Tabakât, 155; Attâr, Tezkiretü'l-evliyâ, 525.

78. Süleyman Uludağ, “Tevhid” Türkiye Diyanet Vakfi İslâm Ansiklopedisi (İstanbul: TDV Yayınlar1, 2012), 41/21.

79. Kuşeyrî, er-Risâletü'l-Kuşeyriyye, 619. Cerîrî tevhidle ilgi kurulacak bir gözlemini de dile getirmektedir. Ona göre "Nimete kulluk edenlerin sayısı çoktur, nimeti verene kulluk edenler nadirdir.” Bu sözüyle o, inanan kimselerin gerçekte nasıl bir kulluk ilişkisinde olduğuna dikkat çekmektedir. Bkz. Kuşeyrî, er-Risâletü’l-Kuşeyriyye, 461.

80. Buhari, "Rikak", 18.

81. Sülemî, Tabakât, 156.

82. Sülemî, Tabakât, 155. 
görevlerinin kaldırılmayacağını iddia etmektedirler. Kuşeyrî teklifin kaldırıldığını iddia eden kimseleri zemmetmektedir. ${ }^{83}$ Cerîrî̀nin ifadesinden anlaşılan ikinci çıkarım ise soru sahibinin insanlardan teklifin düştüğ̈nü kastetmeksizin esasında niyetinin ibadetin zorluğunun manevi olarak kalkıp kalkmayacağıdır. Ancak Cerîrî̀nin cevabının olumsuzluğu, bazı hususları da beraberinde getirmektedir. Birincisi, sülûka yeni başlayan ya da başlangıç makamlarında bulunan kimse için ibadetlerdeki yükün artabileceğidir. İkincisi ise sûfîlerin Hakk'la kurdukları ilişkinin mahiyeti, ibadetlere aşkla yaklaşmasını sağlamaktadır. Dolayısıyla Cerîrînnin ifadesindeki "yük" de ibadetlerdeki niceliksel bir fazlalığa karşılık gelebilir. Cerîrî buna ilaveten ibadetlerdeki yetkinliği ifade edecek "ihlas ve riya” yı gündeme getirir. Ona göre "ihlas yakînin riya tereddüdün eseri-

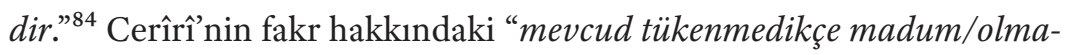
yan talep edilmez" ${ }^{\prime 85}$ tanımı Kelâbâzî tarafından farzları yerine getirme ve rızık istemeyle irtibatı kurularak izah edilmektedir. Kelâbâzî bu sözü şu şekilde izah etmektedir: "Rızık ancak farzları yerine getirmekten aciz kaldiğında taleb edilir." ${ }^{" 16}$

Cerîrî̀nin gündeme getirdiği mevzular arasında "sabır" da bulunmaktadır. O, hem "sabır" hem de "tasabbur" kavramını kullanır. Sabır, nimet ve külfette "kalbin sükunet" halinde kalması anlamındadır; tasabburda ise bela ağırdır. Buna rağmen "kalbin sakinliğì" söz konusudur. ${ }^{87}$ Cerîrî̀nin sabırla kastettiği hususu rıza kavramıyla da açıklamak mümkündür. Zira her şeyin Hakk'tan geldiği inancı hem belada hem de nimette nasıl bir tavır takınılması gerektiğini ortaya koymaktadır.

Cerîrî insanlar arasında bir derecelendirme yaparak onların meselelere kendi mertebelerine göre yaklaşacaklarından bahseder. Mevzu, tasavvuf tarihinde sıkça karşılaşılan bir husustur. Zira sûfîler, herhangi bir kavramı anlatmak istediklerinde "başlangıç, orta ve nihai" makamda kavramın hangi anlama geldiği ya da bu makamlarda kişilerin nasıl bir

83. Kuşeyrî, er-Risâletül-Kuşeyriyye, 71-72.

84. Attâr, Tezkiretü'l-evliyâ, 525 .

85. Serrâc, el-Lüma', 60.

86. Kelâbâzî, et-Taarruf, 112.

87. Kuşeyrî, er-Risâletü’l-Kuşeyriyye, 441. Cerîrîn nin ifadesi şudur: "Sabır odur ki, iki halde de nefs huzur içinde olduğu için nimet ve mihnet halleri arasında fark görmez. Sabır nefsin belada dinginlik ve huzur içinde bulunmasıdır." bkz. Attâr, Tezkiretü’l-evliyâ, 525. 
düşünce içinde bulunduklarına örnek vermektedirler ${ }^{88}$ Cerîrî de konuya dair örnek vermektedir. Örneğin, "avamın himmetinin ulaştığı en son nokta istemek, mutavassitin [tasavvufi terbiyede orta derece olanlarm] dua; âriflerin ise zikirdir"89 diyerek mevzuyu izah etmektedir.

Cerîrî kendi dönemine kadar gelen nesilleri davranışları bağlamında değerlendirmektedir. Ona göre en değerli nesil sahabedir. Zira onlar işlerini dine göre yapmaktadırlar ve ardından gelen asırlarda yaşayan nesiller değer bakımından daha altta yer almaktadırlar. Esasında Cerîrî, nesiller arası bir efdaliyet vurgusu yapmamaktadır ama ifadenin bağlamından bu husus ortaya çıkmaktadır. Cerîrî şöyle söyler: "İlk asırlarda din esasına göre muamele yaparlardı. Onlar geçip gidince din de silinip gitti, ikinci yüzyılda vefa esasına göre muamele yaptılar. Onlar göçüp gidince vefa da ortadan kalktı. Üçüncü yüzyılda mürüvvet esasına göre hareket ettiler. Onlar göçüp gidince mürüvvet de kalmadı. Başka bir yüzyılda haya esasına göre muamele yaptılar. Onlar gidince haya da kalmadı. Şimdi yılgınlık esasına göre muamele yapmaktalar." ${ }^{90}$ Cerîrînin bu ifadeleri toplumdaki hassasiyetlerin zayıfladığını ortaya koymaktadır.

\section{Sonuç}

Ebû Muhammed el-Cerîrî, Bağdat sûfîlerindendir. Onun Cüneyd-i Bağdâdî̀nin halifesi olduğuna dair nerdeyse hiç şüphe yoktur. Tarih kitapları, Cerîrî̀nin Cüneyd'le ilişkisini net bir biçimde ortaya koymaktadır. Cüneyd-i Bağdâdî ile Cerîrînnin arasındaki hoca-öğrenci-halifelik ilişkisi başka bir sûfî için açıkça bu şekilde dile getirilmemektedir. Ancak onun düşünsel anlamda Cüneyd'in fikirlerini sürdürdüğ̈nü söylemek belli kavramlar açısından mümkün görünmemektedir. Cüneyd-i Bağdâdînnin velâyet, fenâ ve bekâya getirdiği yorumlar göz önüne alındığında Cerîrî̀den bu konulara dair herhangi bir görüşünün rivâyet edilmemesi dikkat çekicidir.

88. H. Bayram Başer de makam farklılı̆̆ını sûfîlerin eriştikleri marifet açısından dile getirmektedir. bkz. Hacı Bayram Başer, Şeriat ve Hakikat ile Tasavvufun Teşekkül Süreci (İstanbul: Klasik Yayınları, 2017), 36.

89. Sülemî, Tabakât, 156. Diğer üç örnek de şudur: "Avâmın savaşı tehlikeler, abdâlın savaşı fikir, zâhitlerin savaşı arzular, tevbekârların savaşı hatalar, müritlerin savaşı zevk u sefayladır," "arifeler daha başlangıçta Allah'a başvurur, avâm ise ümit kestikten sonra Allah’a başvurur" ve "şükürdeki kemâl şükürden âciz kalma hâlini görmektir." Bkz. Attâr, Tezkiretüll-evliyâ, 525. 90. Attâr, Tezkiretü’l-evliyâ, 524. 
Cerîrî̀nin tasavvufun birçok kavramına dair açıklamalarda bulunduğu görülmektedir. Bunlar arasında tasavvufun meşhur konularından nefs ve onun terbiyesidir. Cerîrî de her sûfî gibi bu konulara dair fikirlerini dile getirmiştir. Buna ilaveten marifet mevzusuna da değinir ki, bu konuda Cüneyd-i Bağdâdî, onun yetkinliğine dikkat çekmektedir. Cerîrî tevhid, iman, amel, sabır, sülûk gibi konulara az da olsa yeni yorumlar getirmiştir. Kaynaklarda Cerîrî’nin eserinin bulunduğuna dair bir rivâyet yoktur. Onun görüşleri Tabakat literatüründe ve ilk dönem tasavvuf klasiklerinde yer almaktadır.

Çıkar Çatışması / Conflict of Interest: Yazarlar çıkar çatışması olmadığını beyan etmiştir. / The authors declared that there is no conflict of interest.

Finansal Destek / Grant Support: Yazarlar bu çalışma için finansal destek almadıklarını beyan etmiştir. / The authors declared that this study has received no financial support.

Yazar Katkıları / Author Contributions: Yakup Pekdoğru \%75, Harun Alkan \%25.

\section{Kaynakça}

Albayrak, Halis. Tefsir Usûlü. İstanbul: Şule Yayınları, ts.

Algar, Hamid. "Mektûbât". Türkiye Diyanet Vakfi İslâm Ansiklopedisi. 29/11-12. İstanbul: TDV

Yayınları, 2004.

Attâr, Ferîdüddîn. Tezkiretü’l-evliyâ. çev. Süleyman Uludağ. İstanbul: Kabalcı Yayınevi, 2007.

Avcu, Ali. Karmatîlerin Doğuşu ve Gelişimi. Ankara: Ankara Üniversitesi Sosyal Bilimler Enstitüsü, Basılmamış Doktora Tezi, 2009.

Bağdâdî, Hatîb. Târîhu Bağdâd. 16 Cilt. Beyrut: Dâru'l-Garbi'l-İslâmi, 2002.

Ebû Yalâ, Ebü’l-Hüseyn İbn. Tabakātü'l-Hanâbile. 2 Cilt. Beyrut: Dârü'l-Marife, ts.

Bardakçı, Mehmet Necmeddin. İslâm Tasavvuf Düşüncesinin Teşekkülü. İstanbul: Rağbet Yayınları, 2020

Necmeddin, Mehmet. İslâm Tasavvuf Düşüncesinin Teşekkülü. İstanbul: Rağbet Yayınları, 2020. Başer, Hacı Bayram Başer. Şeriat ve Hakikat ile Tasavvufun Teşekkül Süreci. İstanbul: Klasik Yayınları, 2017.

Cebecioğlu, Ethem. Tasavvuf Terimleri ve Deyimleri Sözlïğü. Ankara: Otto Yayınları, 2014. Cerrahoğlu, İsmail. Tefsir Usûlü. Ankara: TDV Yayınları, 2014.

Cürcânî, Seyyîd Şerîf. Ta'rîfât: Tasavvuf Istılahları. çev. Abdülaziz Mecdî Tolun. İstanbul: Litera Yayıncilık. 


\section{Sufiye}

260

Yakup PEKDOĞRU / Harun ALKAN

Demirli, Ekrem. İslâm Metafiziğinde Tanrı ve İnsan. İstanbul: Kabalcı Yayınları, 2012.

Demirli, Ekrem. “Kuşeyrî̀den İbnü'l-Arabî”ye İşâri Yorumculuk Hakkında Bir Değerlendirme: İşarî Yorumdan Tahkîke Doğru Kur’ân-1 Kerim Yorumculuğunun Gelişimi”. Atatürk Üniversitesi İlahiyat Fakültesi Dergisi 40 (2013), 121-142.

Fazlurrahman. İslâm. çev. Mehmet Dağ - Mehmet Aydın. Ankara: Ankara Okulu Yayınları, 2016.

Gökbulut, Süleyman. “Tasavvuf Tarihinde Cüneydî Çizgi”. Dokuz Eylül Üniversitesi İlahiyat Fakültesi Dergisi 36 (2012).

Hücvirî, Ebu'l-Hasan Ali b. Osman. Keşfu’l-mahcûb. çev. Süleyman Uludağ. İstanbul: Dergâh Yayınlar1, 2010.

İbn Hallikan, Ebü’l-Abbâs Muhammed b. İbrâhîm. Vefeyâtü’l-a'yân ve enbâ'ü ebnâ'i'z-zamân. Beyrut: Daru Sadr, 1971.

İbn Manzûr, Ebu’l-Fazl Muhammed. Lisânül-Arab. Kahire: Dâru’l-Maârif, ts.

Teymî, Ebü'l-Kâsım. Siyeru selefi's-sâlihîn. Riyâd: Dâru'r-Râyeti li'n-Neşri ve't-Tevzî, ts.

Kara, Mustafa. "Ebû Muhammed el-Cerîrî”. Türkiye Diyanet Vakfı İslâm Ansiklopedisi. 10 Cilt. İstanbul: TDV Yayınları, 1994.

Karamustafa, Ahmet T. Tasavvufun Oluşumu. İstanbul: Bilgi Üniversitesi Yayınları, 2017.

Kartal, Abdullah. Tasavvufun Oluşumu: Şeriat-Hakikat İlişkisi. Bursa: Emin Yayınları, 2015.

Kelâbâzî, Muhammed b. İbrâhim. et-Taarrufli-mezhebi ehli't-tasavvuf. Beyrut: Dâru'l-Kütübi'lİlmiyye, 2011.

Kılavuz, A. Saim. Anahatlarıyla İslâm Akâidi ve Kelâm'a Giriş. İstanbul: Ensar Yayınları, 2007. Kuşeyrî, Abdülkerîm b. Hevâzin. er-Risâletü'l-Kuşeyriyye. Beyrut: Dâru'l-Minhâc, 2017.

Mekkî, Ebû Tâlib. Kûtü'l-kulûb fî muâmeleti'l-mahbûb ve vasfu tarîki'l-mürîd ilâ makâmi't-tevhîd. 2 Cilt. Beyrut: Dâru Sadır, ts.

Melchert, Christopher. Sünnî Düşüncenin Teşekkülü: Din-Yorum-Dindarlık. çev. Ali Hakan Çavuşoğlu. İstanbul: Klasik Yayınları, 2018.

Öz, Mustafa. "Ebû Tâhir Cennâbî”. Türkiye Diyanet Vakfi İslâm Ansiklopedisi. 7/372-373. İstanbul: TDV Yayınları, 1993.

Özaydın, Abdülkerim. “Bağdat”. Türkiye Diyanet Vakfı İslâm Ansiklopedisi. 4/437. İstanbul: TDV Yayınları, 1991.

Pekdoğru, Yakup. Erken Dönem Tasavvuf Klasiklerinde Marifet: 4-5. Yüzyıllar. Ankara Üniversitesi, Sosyal Bilimler Enstitüsü, Basılmamış Doktora Tezi, 2020.

Safâdî, Ebü's-Safâ. el-Vâfî bi’l-vefeyât. 29 Cilt. Beyrut: Dâru İhyai-Turas, 2000.

Serrâc, Ebû Câfer Nasr. el-Lüma'. Kahire: Dâru'l-Mukattam li’n-Neşr ve’t-Tevzî̀, 2018.

Sübkî, Ebû Nasr Tâcüddîn. Tabakātü'ş-Şâfi'iyyeti'l-kübrâ. 10 Cilt. by.: Hicru li't-Tıbâati ve'nNeşri ve’t-Tevzî, 1413.

Sülemî, Ebû Abdirrahmân. Tabakâtu's-sûfiyye. çev. Abdurrezzak Tek. Bursa: Bursa Akademi, 2018. 
Uludağ, Süleyman. "Halvet Der-Encümen”. Türkiye Diyanet Vakfı İslâm Ansiklopedisi. 15/387388. İstanbul: TDV Yayınları, 1997.

Uludağ, Süleyman. "İşârî Tefsir”. Türkiye Diyanet Vakfi İslâm Ansiklopedisi. 23/424-428. İstanbul: TDV Yayınları, 2001.

Uludağ, Süleyman. "Keşf”. Türkiye Diyanet Vakfı İslâm Ansiklopedisi. 25/315-317. İstanbul: TDV Yayınları, 2002.

Uludağ, Süleyman. "Sülûk”. Türkiye Diyanet Vakfi İslâm Ansiklopedisi. 38/127-128. İstanbul: TDV Yayınları, 2010.

Uludağ, Süleyman. Tasavvuf Terimleri Sözlï̆̈̈̈. İstanbul: Kabalcı Yayınevi, 2012.

Uludağ, Süleyman. “Tevhid”. Türkiye Diyanet Vakfi İslâm Ansiklopedisi. 41/21-22. İstanbul: TDV Yayınları, 2012.

Yılmaz, Hasan Kamil. Anahatlarıla Tasavvufve Tarikatlar. İstanbul: Ensar Neşriyat, 2007.

Zehebî, Ebû Abdillâh Şemsüddîn. Târîhu'l-İslâm ve vefeyâtü'l-meşâhîr ve’l-a'lâm. 37 Cilt. Bsy.: el-Mektebetü't-Tevfîkıyye, Trs.

Zehebî, Ebû Abdillâh Şemsüddîn. Siyeru a'lâmi’n-nübelâ. 18 Cilt. Kahire: Dâru'l-Hadîs, 2006. 
Suline

262

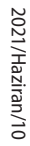

